\title{
International Diversification, Corporate Social Responsibility, And Corporate Governance: Evidence From Korea
}

\author{
Eunho Cho, Sogang University, South Korea \\ Sungbin Chun, Sogang University, South Korea \\ Donseung Choi, Sogang University, South Korea
}

\begin{abstract}
We examine how multinational corporations' (MNC) international diversification (ID) is related to their corporate social responsibility (CSR) activities in the domestic market. We also investigate whether corporate governance, specifically the conglomerate (chaebol) structure, affects the relationship between ID and CSR activities in the domestic market. We perform empirical analysis using a sample of 606 firm-year observations of Korean-listed manufacturing MNCs from 2005 to 2010. We find that ID is negatively associated with CSR, and that this relationship is stronger for chaebol firms. These results are robust after controlling for various factors that affect measurements of ID. Our findings suggest that ID related to market diversification through exports and foreign affiliates appears to push MNCs to perform fewer CSR activities in the domestic market. Our findings also indicate that the effect of chaebol firms on the relationship between ID and CSR is greater than that of non-chaebol firms in Korean market. Our study contributes to the ID and CSR literature as the first study to provide empirical evidence on the association between ID and CSR activities in the domestic market for Korean firms using three aspects of ID measurement. Given that empirical evidence on this issue is very limited, our findings have implications for academics, practitioners, and policymakers in understanding the relationship between ID and CSR strategy.
\end{abstract}

Keywords: Chaebol; Corporate Governance; CSR; International Diversification; MNC

\section{INTRODUCTION}

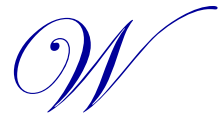
e empirically investigate whether multinational corporations' (MNC) international diversification (ID) is associated with their corporate social responsibility (CSR) activities in the domestic market. We also analyze how corporate governance, specifically the conglomerate (chaebol) structure, affects the relationship between ID and CSR. Debates over CSR have been spreading for the past three decades. However, firms are still considering whether they should perform CSR activities voluntarily, actively, and persistently. Some firms perform CSR activities proactively in an effort to solve social problems, whereas other firms engage in CSR activities simply out of obligation driven by social pressure or trends. Prior studies on CSR question whether firms must engage in CSR in the market in which they operate their business. In an early CSR study, Friedman (1970) argues that the objective function of firms is most likely to maximize profits within the framework of traditional economics. That is, firms play an important role in creating wealth through competition and cooperation in the market, implying that CSR is not firms' responsibility. However, as the awareness and power of citizens have grown, firms have not been expected to simply pursue profits but must also take on social responsibility as a member of society (Van Marrewijk 2003). Stakeholder theory (Freeman 1984) also emphasizes the importance of stakeholder ${ }^{\mathrm{i}}$ management for firm value in the long run. ${ }^{\text {ii }}$ 
In an era of globalization and ever-increasing stakeholder demands, most global companies are concerned with and are actively engaged in CSR activities. According to a KPMG (2008) survey on practitioners, $80 \%$ of the top 250 Fortune Global 500 firms issued sustainability reports and approximately $75 \%$ of the survey respondents recognized CSR as an important part of their business strategies. Because numerous practitioners and researchers recognize the importance of CSR, they fundamentally question whether CSR activities contribute to firms' financial performance and value. In a recent study, Aguinis and Glavas (2012) comprehensively review the CSR literature based on 588 journal articles and 102 books published during 1970-2011 and suggest that the prior studies do not provide consistent empirical results on the relationship between CSR and financial performance. ${ }^{\text {iii }}$

Then, what factors influence corporations' CSR activities? We focus on the importance of MNCs' role in the global market as corporations' internationalization processes advance. Furthermore, a MNC's global strategy is affected by ISO26000, ${ }^{\text {iv }}$ particularly with respect to CSR and ID. Accordingly, in this study we address the question from a strategic point of view of how MNCs' ID is associated with their CSR activities in the domestic market. Although both ID and CSR have recently become more important elements of a firm's strategy to remain competitive and sustainable (Sharfman et al. 2004), to date not much is known about the relationship between ID and CSR (Kang 2013). Moreover, despite increasing attention paid to CSR in recent years, the social and corporate awareness of CSR in Asian countries is still relatively low (Ip 2008). To date, studies on CSR and related issues primarily focus on CSR practices in western countries (Belal 2001), whereas empirical evidence on the CSR issue in developing countries is limited (Gao 2011; Scholtens and Kang 2012). Because most large Korean companies are MNCs and are actively engaged in ID, exploring the manner in which the degree of ID of Korean MNCs affects CSR activities in the domestic market is opportune and interesting.

Prior studies on MNCs provide a theoretical background on the relationship between ID and CSR. Low and Yeats (1992) and Lucas et al. (1992) argue that MNCs enter overseas markets to avoid social or environmental regulations in their domestic markets. Kang (2013) argues that the ID of firms is positively associated with CSR activities because MNCs need to meet increasing multiple stakeholder demands as ID progresses. In other words, firms pursuing ID should comply with international standards and should confront the stronger pressure from multiple stakeholders, more so than non-MNCs (Sharfman et al. 2004). Meanwhile, Strike et al. (2006) document that MNCs simultaneously show both responsible and irresponsible behavior as ID progresses. Thus, the mixed findings demand more and further research in this area using various samples and methodologies in different countries to clarify the association between ID and CSR, and to draw generalizable conclusions. ${ }^{v}$

Our primary motivation for conducting this investigation is to analyze whether market diversification through ID changes the level of CSR activities in the domestic market. In Korea, chaebols that often have complex shareholding arrangements can heavily impact a firm's corporate governance and performance outcomes (Brown et al. 2011). We also use chaebol ${ }^{\mathrm{vi}}$ firms as a proxy for corporate governance, an approach that is unique to the Korean market because chaebols are largely controlled by families of founders and have more centralized ownership than non-chaebols (Kienzle and Shadur 1997). Moreover, the Korean chaebol system is more dominant than the keiretsu system $^{\text {vii }}$ in Japan (Campbell and Key 2002). Additionally, because chaebol firms in Korea developed a highly centralized decision-making system controlled by a few key shareholders on the solid foundation of strong control through family and interlocking ownership, the possibility is low that agency problems occur between stockholders and managers. Park and Yuhn (2012) document that Korean chaebol firms obtain a net gain in technical efficiency and have a competitive advantage in product pricing and capital financing. In this context, we additionally examine whether Korean chaebol firms show a differential relationship between ID and CSR in the domestic market compared with non-chaebol firms.

We employ a sample of 606 firm-year observations of Korean-listed manufacturing MNCs from 2005 to 2010. Our empirical results indicate that ID of MNCs negatively and significantly affects firms' CSR activities in the domestic market. One interpretation of this result is that the negative relationship results from the economy of scope (Ghoshal 1987; McWilliams and Siegel 2001) and synergy effects realizable by ID. Another interpretation is that this negative relationship is simply due to decreasing importance of the domestic market relative to all of the markets in which MNCs operate. Our finding suggests that the effect of chaebols on the negative relationship between ID and CSR in the domestic market is stronger than that of non-chaebol firms, supporting the contention that corporate governance structures affect a firm's strategic decisions (Cretu 2012; Steyn and Niemann 2014) such 
as ID and CSR, as studied in our paper. Our empirical results are robust after we control for three individual components of ID measures in our multivariate analysis.

Our study contributes to the literature on ID and CSR in several areas. First, this study is the first to provide empirical evidence on the relationship between ID and CSR in the domestic market by focusing on Korean MNCs in Asia, a region that comprises a large portion of the world economy but that is relatively neglected by researchers in prior studies. One advantage of using Korean firms is that we can test whether a unique Korean corporate governance system, namely the highly centralized and owner-dominant chaebol structure, is a moderating factor that affects the relation between ID and CSR in the domestic market. Many studies report that CSR is specific to the culture and differs across cultures (Carroll 1993). Daft (2010) also argues that prior research results indicate that firms in Europe, the United States, and Asia show different management styles and patterns. Our study primarily differs from existing studies in that we analyze corporate governance effects using chaebols on the relationship between ID and CSR activities in the domestic market. Second, our evidence has an important implication to practitioners. If ID affects CSR, our findings are useful to practitioners in understanding whether a proper level of CSR activities exist in the context of the overall business strategy, particularly the ID strategy in this study. Third, following Strike et al. (2006), we employ more extensive measures of ID using export amount, number of affiliates, and foreign countries to secure the robustness of the empirical results. Finally, evidence from this study is helpful to regulators and standard-setters in better understanding the relationship between and function of ID and CSR in the domestic market.

The remainder of the paper is as follows. First, we provide a literature review and develop the hypotheses. Second, we describe the data and sample selection, measurements of the selected variables, and the research model. Third, we show and discuss the empirical results. Finally, we summarize and conclude.

\section{LITERATURE REVIEW AND HYPOTHESIS DEVELOPMENT}

Figure 1 presents the research model of this study. This line of research examines whether MNCs' ID is associated with CSR activities in the domestic market (H1) and whether corporate governance affects the relationship between MNCs' ID and CSR activities in the domestic market (H2).

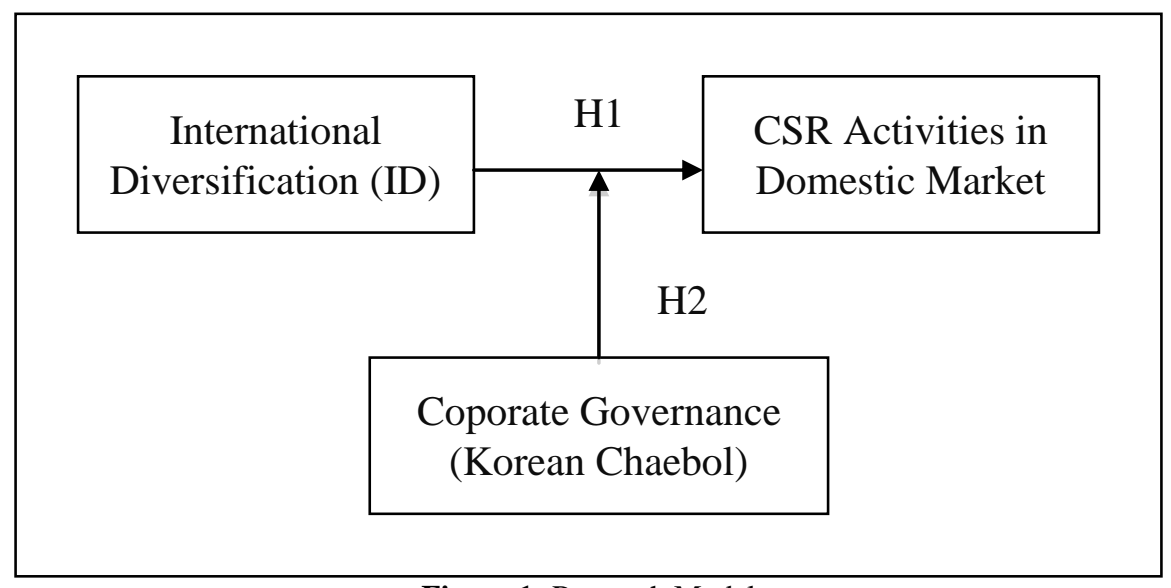

Figure 1: Research Model

\subsection{International Diversification}

Ever-increasing globalization and IT development are driving firms to rapidly adapt to constantly changing business environments and to continue to diversify their geographic scope to pursue competitive advantages (Porter 1990; Majumdar and Ramaswamy 1995). ID is defined as expanding firms' activities to other markets in different geographic locations that cross national borders (Hitt et al. 1997). ID is associated with a number of different markets related to export and overseas affiliates. In the past, Korea achieved significant economic growth through a strong export-driven policy supported by the Korean government. This export-driven 
policy helped Korean firms increase their competitive advantage in the global market. In terms of Korean firms' 2014 exports, the Korean export market share ranks seventh in the world, ${ }^{\text {viii }}$ indicating that Korean firms rely heavily on exports. Regarding foreign affiliates, the Statistics Research Institute (2009) reports that 2,395 Korean firms have 5,568 foreign affiliates as of December 31, 2007, of which manufacturing domestic firms and affiliates account for $75 \%$ and $73 \%$, respectively - the largest industry proportion in Korea. In the future, the ID strategy of firms is expected to further strengthen as an alternative to solving trade barriers and having a competitive advantage.

Firms have incentives to diversify their markets to take advantage of market imperfections (Errunza and Senbet 1981, 1984), such as low raw material prices and low labor force costs, loose environmental regulations, and loose safety standards. However, when MNCs enter overseas markets through exports and foreign affiliations, they need to enhance their firms' reputation and brand image by overcoming the liability of foreignness (Zaheer 1995). Firms pursuing ID must behave in a socially responsible manner, which is not an option but an imperative (Christmann 2004). Stakeholders also increasingly demand that MNCs take responsibility for the society in which they operate. McWilliams and Siegel (2001) show that managers need to devote resources to CSR to meet growing multiple stakeholder demands. MNCs must manage their firms' image and the brand image they use with foreign affiliates because bad behavior is likely to damage MNCs' precious image and brand value (Kang 2013).

\subsection{Corporate Social Responsibility}

CSR is an actively discussed topic in business research. Although the meanings and concepts of CSR have been discussed extensively, no clear consensus exists among scholars and practitioners regarding the definition of CSR (Dahlsrud 2008). This phenomenon is likely to indicate that CSR has been applied to various fields and that firms' perceptions of their roles in relation to CSR have changed as they follow current trends. Scholars and organizations suggest numerous definitions of CSR (e.g., Carroll 1979, 1991; World Business Council for Sustainable Development 1999; McWilliams and Siegel 2001). Among them, the definition suggested by Carroll (1991) is widely accepted by many studies. ${ }^{\text {ix }}$

Carroll (1979, p. 500, 1991, p. 283) suggests the following CSR definition: "The social responsibility of business encompasses the economic, legal, ethical, and discretionary (later revised as philanthropic) expectations that society has of organizations at a given point in time." That is, Carroll (1991) divides CSR into economic, legal, ethical, and philanthropic responsibilities, suggesting that economic and legal responsibilities are required, ethical responsibilities that are expected, and philanthropic responsibilities are desired by society. The theoretical discussion on CSR has been expanded following his four-part definition. Recent studies continue to examine alternative concepts of CSR, such as corporate citizenship (Wood and Lodgson 2002; Matten et al. 2003) or corporate sustainability (Van Marrewijk 2003; Montiel 2008). However, the root of these concepts is still similar to the original definition of CSR by Carroll (1991).

A theoretical development has occurred regarding CSR. During the very early stages of CSR studies, Bowen (1953) suggests in his book, Social Responsibilities of the Businessman, that CSR in the 1950s focused on CEO activities and primarily concerned activities at the individual level. Then, Friedman (1970) argues that the one and only social responsibility of business is to use its resources and engage in activities designed to maximize its profits. Namely, Friedman (1970) emphasizes that firms' primary responsibility is to conduct business to maximize stockholders' and not stakeholders' profits. In contrast, as social issues (e.g., race and sex discrimination, pollution, fair trade) appear, stakeholders surrounding firms start to demand visible efforts from firms that exist in the center of social issues.

Under these circumstances, stakeholder theory (Freeman 1984) developed, which emphasizes CSR activities on the basis of organizational level. Freeman (1984) argues that the notion that managers have a duty to stockholders must be replaced by the notion that managers bear a fiduciary relationship to stakeholders such as suppliers, customers, employees, stockholders, and the local community. Following this argument, firms tend to actively solve social issues related to stakeholders and develop systematic implementation plans across the board (Carroll 1993). In a recent study, Idowu and Towler (2004) point out that firms obtain significant benefits when their stakeholders perceive them as socially responsible. 
CSR includes voluntary activities engaged in moral motives to meet social promises or obligations to various stakeholders beyond minimum legal requirements. The recent theoretical and practical discussion on CSR based on various perspectives regards CSR as an investment concept rather than an expense and as a differentiation strategy that enhances the competitive advantage (McWilliams and Siegel 2000; Porter and Kramer 2002; McWilliams et al. 2006).

\subsection{ID And CSR}

Two studies directly examine the relationship between ID and CSR. Using a sample of 3,044 firm-year observations of U.S. firms from 1993 to 2006 and KLD data, Kang (2013) documents that unrelated diversification of large U.S. firms is positively associated with their CSR activities, whereas related diversification is not significantly related to CSR activities. Kang (2013) also finds that international diversification is positively associated with firms' CSR. These results suggest that diversified firms more frequently face and address increasing stakeholder demands than other firms. However, Strike et al. (2006) examine the relationship between ID and CSR activities using 222 MNCs in the United States from 1993 to 2003 and KLD data, and report that MNCs simultaneously engage in both responsible and irresponsible behavior as ID progresses. Therefore, the relationship between ID and CSR activities may have not just one direction but also two directions depending on the situation.

Prior studies allow us to predict that ID is positively associated with CSR in the total markets in which firms operate. The incentive for firms to employ an ID strategy is related to the creation of greater opportunities and higher profits (Kogut 1985). If MNCs must manage multiple stakeholder demands to support their reputation in both overseas markets and the domestic market in which they are located, they must fulfill their CSR in both markets to maintain and promote brand power and firms' image. CSR is highly likely to increase brand value and firms' image (Orlitzky et al. 2003; Brammer and Pavelin 2006a). Thus, MNCs entering various overseas markets must comply with international standards related to the labor environment and face pressure to achieve higher levels of CSR to enhance a firm's reputation (Sharfman et al. 2004). Thus, MNCs have strong incentives to perform CSR in both the domestic market and foreign markets as ID progresses to differentiate themselves from their competitors, leading to a positive relationship between ID and CSR in the total market.

However, the association between ID and CSR in the domestic market may be positive or negative. One scenario is that ID is positively related to CSR in the domestic market. As stakeholders increasingly demand that their expectations be met, firms' CSR activities are expected to increase to satisfy multiple stakeholders, manage relationship with stakeholders, and enhance their brand image. Another scenario is that ID is negatively associated with CSR in the domestic market. Because ID is likely to help MNCs better realize economy of scope and synergy effects, it is known as a contributing factor to the economy of scope that drives MNCs to lower average CSR expenditure per affiliate (Ghoshal 1987; McWilliams and Siegel 2001). Firms are motivated to enter the overseas market to avoid strict environmental regulations of the domestic market (Rugman 1979) and to obtain abundant and cheap labor available in foreign local markets (Shahrohk 2002). However, MNCs entering various overseas markets must comply with international standards related to the labor environment and face pressure to achieve higher levels of CSR to enhance their firms' reputation (Sharfman et al. 2004). Then, they need to perform CSR activities (e.g., donations, education, medical activities) in the foreign local market. Moreover, MNCs accomplish CSR in foreign local markets to differentiate themselves from their competitors.

Thus, if CSR activities occur in foreign local markets, such activities in the domestic market are likely to decrease given economy of scope and synergy effects. In addition, from a different perspective, we expect that relatively less importance is placed on the domestic market as ID progresses. That is, if MNCs expand into the overseas market, they must consider a global portfolio of all affiliates, including in the Korean market. Thus, the greater the weight they place on the global market, the less important the Korean domestic market becomes. In summary, ID is positively associated with CSR in total markets. However, CSR activities in the domestic market may either increase due to increased multiple stakeholder demands or decrease given synergy effects of ID and/or the diminishing importance of the domestic market compared with the global markets. Therefore, the degree of ID is expected to be either negatively or positively associated with CSR activities in the domestic market. Based on these discussions, we conclude that the direction of the relationship between ID and CSR activities in the domestic market 
remains an empirical question, and we do not predict a specific direction. Thus, we propose the following hypothesis (H1).

Hypothesis 1: Ceteris paribus, a significant relationship exists between MNCs' ID and CSR activities in the domestic market.

\subsection{Corporate Governance Of Chaebols, And The Relationship Between ID And CSR}

In East Asian countries, controlling shareholdings and cross-shareholdings are common and have a big impact on corporate governance (Brown et al. 2011). Namely each country, particularly developing countries, may have a large business group in the process of experiencing economic growth. In Korea, these business conglomerates are called chaebols. Granovetter (1995) defines a business group as a group of firms bound by formal or informal structures but that remain legally separated. In the past, as Korea implemented economic development plans driven by the government, the chaebols flourished in various business fields. The chaebol firms played a key role in Korea's rapid economic growth and grew under the umbrella of government protection.

The separation of ownership and management under developed capitalism has been causing agency problems (Jensen and Meckling 1976). In particular, the information asymmetry between the principal (shareholders) and the agent (managers) triggers shareholders' monitoring activities, which are likely expensive and have fundamental limitations. However, chaebol firms in Korea developed a highly centralized decision-making system controlled by a few key shareholders on the solid foundation of strong control through family and interlocking ownership. Thus, the possibility is low of agency problems between stockholders and managers. Furthermore, chaebol firms are more likely to realize higher profitability than non-chaebol firms because the organizational structure of chaebols is efficient and helps affiliated firms share resources, thereby overcoming market imperfections and promoting the efficient distribution of resources (Shin and Park 1999; Chang and Hong 2000). Park and Yuhn (2012) also document that Korean chaebol firms obtain a net gain in technical efficiency and have a competitive advantage in product pricing and capital financing. In Korea, business group known as chaebol can have a big impact on a firm's corporate governance (Brown et al. 2011). Many researchers (Campbell and Keys 2002; Albrecht et al. 2010; Oh et al 2011; Park and Yuhn 2012; Choi et al. 2013) have a strong interest in Korean chaebols.

Thus, we explore how corporate governance, specifically the chaebol conglomerate structure, affects the relationship between ID and CSR in the domestic market. Accordingly, we predict that this relationship is stronger under the strong leadership and efficiency of chaebol firms. Korean chaebol firms are known to have more abundant and productive resources than non-chaebol firms. For example, the proportion of managers in chaebol firms is higher than that in non-chaebol firms (Lee et al. 1991), suggesting the following hypothesis (H2).

Hypothesis 2: Ceteris paribus, corporate governance of chaebol firms strengthens the relationship between MNCs' ID and CSR activities in the domestic market.

\section{RESEARCH DESIGN}

\subsection{Data And Sample Selection}

We collect our sample from the KisValue, TS2000, provided by the Korea Listed Companies Association and the Korea Economic Justice Institute (KEJI). We restrict our sample to 606 manufacturing MNCs' firm-year observations with at least one foreign affiliate, are listed on the Korea Stock Exchange, and have a CSR score provided by KEJI. Because the ID strategy of Korean firms is most pronounced in the manufacturing sector, the manufacturing industry is considered a proper sample group because it accounts for the largest segment in Korea and is related to product export and an expanding overseas market. ${ }^{\mathrm{x}}$ Further, each firm-year observation must have the available data necessary to calculate ID and control variables. The final sample includes 606 firm-year observations for the 2005-2010 period. 


\subsection{Measurements Of CSR, ID, Control Variables, And Chaebol}

We use CSR_SCORE (the level of CSR activities) as the dependent variable and INTL_DIV (international diversification) as the main independent variable of interest. We use various control variables to control for confounding effects in multiple regression analyses, including $R D \_I N T$ (R\&D intensity), $A D \_I N T$ (advertising intensity), RISK (risk), ASEET_AGE (asset age), ROS (return on sales), SLACK (slack resources), INST (institutional ownership), FORE (foreign ownership), and $O W N_{-} C O N$ (ownership concentration).

\subsubsection{CSR_SCORE: KEJI Index (Dependent Variable)}

Because the KEJI is a civic group that is relatively free from unhealthy links between business and politics, it is likely to evaluate firms' social performance more objectively and fairly than other institutions. In 1990, the KEJI Index was developed by more than 50 experts, such as professors in business, economics, sociology, and law, and by lawyers and accountants. In other words, the KEJI Index owns more than 20 years of history. Since then, the KEJI Index has been modified several times to reflect changes in the social environment. The KEJI Index is comparable to the Council on Economic Priorities (CEP) Index, the Asahi Index (KEJI 2011), and the KLD ratings (Oh et al. 2011) in that they have a similar measurement index such as a firm's financial soundness and the degree of a firm's engagement in social and environmental issues. Thus, numerous prior studies use the total CSR score assessed by the KEJI (e.g., Choi et al. 2010; Oh et al. 2011; Choi et al. 2013).

Although the KEJI announces only the top 200 best corporate citizens annually, we secure a list of more than 300 firms each year that contains non-announced firms to ensure that our results are likely to have more power from the larger sample size to detect the relationship between ID and CSR. ${ }^{\mathrm{xi}}$ The seven sections of the KEJI Index measurement consist of soundness (20 points), fairness (11 points), social contribution (7 points), customer protection and satisfaction (7 points), environmental protection activity (10 points), employee satisfaction (10 points), and economic development contribution (10 points). The total score of the KEJI Index is 75 based on quantitative data from many sources, such as the Korea Investors Services Inc., the Department of Environment, the Korea Consumer Protection Board, and the National Assembly, among others (KEJI 2011).

\subsubsection{INTL_DIV: International Diversification (Main Variable of Interest)}

International diversification is defined as expanding firms' activities to other markets in different geographic locations that cross national borders (Hitt et al. 1997). Following Strike et al. (2006), we measure the extent of ID using factor analysis and data on 1) foreign market penetration, as measured by export percentage of total sales and 2) foreign market presence, as measured by the number of foreign affiliates and countries. To secure various aspects of ID measure, we manually collect data on affiliates of Korean-listed manufacturing MNCs from TS2000. We classify manufacturing firms by country name as included and shown in foreign affiliates' name because TS2000 does not directly provide us with the data we want to employ in our analysis.

All three indicators are standardized before performing factor analysis, and the eigenvalue of the unique factor is 2.03. The Cronbach's alpha for the three indicators is 0.709 , indicating a proper level of reliability ${ }^{\text {xii }}$ Each three standardized indicators, and the combined value of the standardized three indicators, are calculated and used in the following empirical analysis.

\subsubsection{Control Variables}

To avoid the problem of correlated omitted variables, we include various control variables that might affect CSR activities. McWilliams and Siegel (2000) find that R\&D and advertising intensity are positively associated with CSR because they promote product differentiation through innovation and advertisement, respectively. Thus, we include $R D_{-} I N T$ and $A D_{-} I N T$ as proxies for $\mathrm{R} \& \mathrm{D}$ and advertising expenditures, respectively. Orlitzky and Benjamin (2001) show that CSR is more strongly correlated with measures of market risk than measures of accounting risk. Alexander and Buchholz (1978) measure market risk using beta. Following these studies, to control for risk factors related to CSR, we include RISK measured by beta, known as the measure of systematic or market risk on the security market line. Cochran and Wood (1984) show that asset age is highly correlated with social responsibility ranking. If firms have old age assets, CSR tends to reduce diversifiable market 
risk (Orlitzky and Benjamin 2001). That is, firms with more old age assets tend to increase their CSR activities. Thus, we include ASSET_AGE, measured as the net amount of property, plant, and equipment (PPE) divided by the gross amount of PPE and multiplied by -1 to ensure that assets with higher values have older ages. Prior studies (e.g., Waddock and Graves 1997; McWilliams and Siegel 2000; McGuire et al. 2003) report that firm size and profitability are positively correlated with CSR activities. Brammer and Pavelin (2006b) also suggest that larger firms are more likely to engage in CSR activities to have better relationships with stakeholders. Thus, we include SIZE and ROS variables as proxies for firm size and return on sales, represented by the natural logarithm of total assets and earnings before interest and taxes (EBIT) divided by lagged net sales, respectively. The slack resources theory (Waddock and Graves 1997) suggests that if firms have more organizational slack resources, they are more likely to be committed to CSR activities. Thus, we control for SLACK, measured as the current ratio, i.e., current asset divided by current liabilities. Previous research finds that ownership structure influences organizational decision making and motivation (Hart and Moore 1990; Finkelstein 1992). Prior studies show that institutional investors positively influence firms' CSR activities (Graves and Waddock 1994; Oh et al. 2011), and the size of foreign shareholders is positively associated with CSR (Choi and Aguilera 2009; Oh et al. 2011). However, top manager shareholdings are reported to be negatively associated with a firm's CSR activities (Oh et al. 2011). Thus, we include INST, measured as the sum of the share percentage owned by institutional owners; FORE, measured as the sum of the share percentage owned by foreign owners; and $O W N_{-} C O N$, measured as the sum of the share percentage owned by the three largest shareholders.

\subsubsection{Chaebols}

We obtain a list of the 30 largest chaebols in Korea from the Korean Fair Trade Commission, which provides detailed information on large business groups.

\subsection{Research Model}

To capture the relationship between ID and CSR activities, we estimate the following model:

$$
\begin{gathered}
C S R \_S C O R E_{i, t}=\alpha_{0}+\alpha_{1} I N T L_{-} D I V_{i, t}+\alpha_{2} R D_{-} I N T_{i, t}+\alpha_{3} A D_{-} I N T_{i, t}+\alpha_{4} R I S K_{i, t} \\
+\alpha_{5} A S S E T \_A G E_{i, t}+\alpha_{6} S I Z E_{i, t}+\alpha_{7} R S_{i, t-1}+\alpha_{8} S L A C K_{i, t}+\alpha_{9} I N S T_{i, t} \\
+\alpha_{10} F O R E_{i, t}+\alpha_{11} O W N_{-} C O N_{i, t}+\sum I N D_{i, t}+\sum Y E A R_{i, t}+\varepsilon_{i, t}
\end{gathered}
$$

where, for company $i$ in period $t$ :

CSR_SCORE = net score of CSR activities, measured as the KEJI Index and consisting of seven categories: soundness, fairness, social contribution, customer protection \& satisfaction, environmental protection activity, employee satisfaction, and economic development contribution;

INTL_DIV = standardized score of international diversification, measured by combining three indicators using factor analysis, where the three indicators are one measure of foreign market penetration (export amount / total sales amount) and two measures of foreign market presence (the number of foreign subsidiaries held by the firm and the number of countries in which subsidiaries are located);

RD_INT = R\&D intensity $(\mathrm{R} \& \mathrm{D}$ expenses/net sales);

$A D \_I N T=$ advertising intensity (advertising expenses/net sales);

RISK = beta, as measured by systematic risk using the market model;

ASSET_AGE = asset age, - (PPE net amount/ PPE gross amount);

SIZE = natural logarithm of total assets, $\ln$ (total assets), at year-end;

ROS $\quad$ = return on sales (EBIT/lagged net sales);

SLACK = slack resources (current assets/current liabilities) at year-end;

INST = institutional investors' ownership, sum of the percentage of shares held by institutional investors at year-end;

FORE = foreign investors' ownership, sum of the percentage of shares held by foreign investors at year-end; and,

OWN_CON = ownership concentration, sum of the percentage of shares held by the three largest shareholders at year-end. 
We estimate Equation (1) using multiple regressions. We include industry and year dummies to control for industry (based on the two-digit KSIC ${ }^{\text {xiii }}$ classification) and year (2005-2010) differences in CSR activities.

\section{EMPIRICAL RESULTS}

\subsection{Descriptive Statistics And Univariate Analysis}

Table 1 shows the major portion of the sample distribution of firm-year observations using the two-digit KSIC industry code. The most heavily represented industry is chemicals and chemical products (15.51\%, KSIC 20), followed by electronic components, computer (13.53\%, KSIC 26), and motor vehicles and trailers (13.53\%, KSIC 30). The highest mean value for CSR_SCORE is 55.75 (KSIC 12) for the tobacco product industry, indicating that this industry seems to carry out CSR activities to improve its brand image and avoid negative criticism. The second highest CSR score belongs to the other transport equipment industry (49.66, KSIC 31). The highest mean value of ID is 0.691 (KSIC26), indicating that electronic components MNCs have high portion of exports and a number of foreign affiliates. The next highest mean value of ID is the other transport equipment industry, with a mean of 0.415 (KSIC 31), indicating that other transport equipment actively enters overseas markets.

Table 1: Sample Description: Distribution Of Firm-Year Observations By Industry

\begin{tabular}{lc|c|c|cc}
\hline & & $C S R_{-} \boldsymbol{S C O R E}$ & ID & \multicolumn{2}{c}{ Distribution } \\
\hline Industry & Two-Digit KSIC & Mean & Mean & \# ofM Obs. & \% of Sample \\
\hline Tobacco products & 12 & 55.75 & -0.223 & 5 & $0.83 \%$ \\
\hline $\begin{array}{l}\text { Chemicals and chemical products excluding } \\
\text { pharmaceuticals, medicinal chemicals }\end{array}$ & 20 & 46.68 & -0.013 & 94 & $15.51 \%$ \\
\hline $\begin{array}{l}\text { Electronic components, computer, radio, } \\
\text { television \& communication equipment }\end{array}$ & 26 & 46.57 & 0.691 & 82 & $13.53 \%$ \\
\hline Motor vehicles, trailers, and semitrailers & 30 & 44.18 & -0.005 & 82 & $13.53 \%$ \\
\hline Other transport equipment & 31 & 49.66 & 0.415 & 14 & $2.31 \%$ \\
\hline Total & & 45.95 & 0.009 & & \\
\hline
\end{tabular}

Note: This table only shows a major proportion of all distributions

Table 2 shows descriptive statistics for selected variables and Pearson's correlations. Panel A of Table 2 reports mean values for CSR_SCORE (45.952) and INTL_DIV (0.009). The mean values for RD_INT and AD_INT are 0.019 and 0.009 , respectively, indicating that, on average, $1.9 \%$ and $0.9 \%$ of net sales are invested in R\&D and advertising expenditures, respectively. We also find that the mean of RISK, as measured by beta from the market model, is 0.871 , indicating that systematic risk or market risk is relatively low considering that the beta of the market portfolio (e.g., KOSPI) is 1 . The mean value of $A S S E T \_A G E$ is -0.555 , suggesting that firms are, on average, maintaining slightly longer than the middle level of the useful PPE period. The mean value of SIZE is 27.056 , i.e., 562.6 billion Korean won. The average value of $R O S$ (return on sales) is 0.069 , indicating that our sample firms are profitable on average. Not surprisingly, both listed firms and CSR-performing firms are profitable. ${ }^{\text {xiv }}$ The mean value of SLACK, the current ratio (current assets divided by current liabilities), is 1.904, indicating that the shortterm liquidity of sample firms is high and enough for performing CSR activities. The average ownership percentage held by institutional investors (INST), foreign investors (FORE), and the three largest owners (OWN_CON) are approximately $2 \%, 15 \%$, and $40 \%$, respectively, indicating that Korean MNCs have a relatively lower level of institutional investors $(2 \%)$ than foreign investors $(15 \%)$ and a high portion of large stockholders $(40 \%)$.

Panel B of Table 2 shows the Pearson's correlation coefficients for selected variables. CSR_SCORE is positively correlated with INTL_DIV, RD_INT, AD_INT, SIZE, ROS, SLACK, INST, and FORE, and negatively correlated with $O W N_{-} C O N$. The correlations are statistically significant, suggesting that firms' size, profitability (measured as ROS), and liquidity (measured as SLACK, i.e., current ratio) are likely to be related to more CSR activities, whereas ownership concentration is less likely to promote CSR activities. We also observe that the correlation coefficient between SIZE and INTL_DIV is 0.596, or slightly higher than 0.5 , which might cause multicollinearity. However, we decide to include the SIZE variable in our model for the following reasons. First, SIZE is a widely accepted and used control variable in most business research models to control for the confounding 
effect. Second, we also check for multicollinearity using variation inflation factors (VIF) in our analysis model and find no multicollinearity problem in our sample.

Table 2: Descriptive Statistics Of Selected Variables And Pearson's Correlations

\begin{tabular}{lcccccc}
\hline Panel A: Full Sample & \multicolumn{1}{c}{} & & & \\
\hline Dependent Variables & $\mathbf{n}$ & Mean & Median & Std. Dev. & $\mathbf{2 5}^{\text {th }}$ Percentile & $\mathbf{7 5}^{\text {th }}$ Percentile \\
\hline CSR_SCORE & 606 & 45.952 & 45.697 & 3.566 & & 43.552 \\
\hline Variable of Interest & & & & & & \\
\hline INTL_DIV & 606 & 0.009 & -0.222 & 1.051 & -0.479 & 0.031 \\
\hline Control Variables & & & & & & \\
\hline RD_INT & 606 & 0.019 & 0.012 & 0.021 & 0.004 & 0.026 \\
AD_INT & 606 & 0.009 & 0.001 & 0.019 & 0.000 & 0.006 \\
RISK & 606 & 0.871 & 0.855 & 0.350 & 0.621 & 1.120 \\
ASSET_AGE & 606 & -0.555 & -0.558 & 0.140 & -0.658 & -0.468 \\
SIZE & 606 & 27.056 & 26.634 & 1.562 & 25.941 & 28.043 \\
ROS & 606 & 0.069 & 0.057 & 0.052 & 0.033 & 0.087 \\
SLACK & 1.904 & 1.413 & 1.546 & 1.046 & 2.158 \\
INST & 606 & 2.193 & 0.000 & 6.094 & 0.000 & 0.000 \\
FORE & 606 & 15.437 & 9.605 & 16.631 & 2.360 & 23.360 \\
OWN_CON & 606 & 39.905 & 39.295 & 13.154 & 30.140 & 48.400 \\
\hline
\end{tabular}

The variables are defined in Appendix A.

\section{Panel B: Correlations Among CSR, Int'I Diversification, And Other Variables}

\begin{tabular}{|c|c|c|c|c|c|c|}
\hline & 1 & 2 & 3 & 4 & 5 & 6 \\
\hline 1. CSR_SCORE & 1.000 & & & & & \\
\hline 2. INTL_DIV & $0.309 * *$ & 1.000 & & & & \\
\hline 3. RD_INT & $0.221 * *$ & $0.293 * *$ & 1.000 & & & \\
\hline 4. $A D \_I N T$ & $0.297 * *$ & 0.009 & 0.033 & 1.000 & & \\
\hline 5. RISK & 0.073 & $0.270 * *$ & -0.013 & $-0.202 * *$ & 1.000 & \\
\hline 6. ASSET_AGE & 0.034 & 0.078 & $0.138 * *$ & $-0.113^{* *}$ & -0.021 & 1.000 \\
\hline 7. SIZE & $0.563 * *$ & $0.596 * *$ & 0.074 & $0.124 * *$ & $0.358 * *$ & $-0.170 * *$ \\
\hline 8. $R O S$ & $0.375^{* *}$ & $0.103 *$ & $0.089 *$ & $0.229 * *$ & 0.006 & $-0.096^{*}$ \\
\hline 9. SLACK & $0.140 * *$ & $-0.114 * *$ & 0.072 & -0.065 & $-0.226 * *$ & $0.207 * *$ \\
\hline 10. INST & $0.228 * *$ & $0.130 * *$ & $0.107 * *$ & -0.025 & $0.167 * *$ & $-0.127 * *$ \\
\hline 11. FORE & $0.459 * *$ & $0.277 * *$ & $0.124 * *$ & $0.251 * *$ & 0.056 & $0.092 *$ \\
\hline 12. OWN_CON & $-0.109 * *$ & $-0.164 * *$ & -0.015 & $-0.093 *$ & -0.058 & -0.044 \\
\hline \multirow[t]{2}{*}{$\mathrm{N}$} & 606 & 606 & 606 & 606 & 606 & 606 \\
\hline & 7 & 8 & 9 & 10 & 11 & 12 \\
\hline 7. SIZE & 1.000 & & & & & \\
\hline 8. $R O S$ & $0.362 * *$ & 1.000 & & & & \\
\hline 9. SLACK & $-0.109 * *$ & $0.131 * *$ & 1.000 & & & \\
\hline 10. INST & $0.334 * *$ & $0.114 * *$ & $-0.109 * *$ & 1.000 & & \\
\hline 11. FORE & $0.510 * *$ & $0.343 * *$ & $0.207 * *$ & 0.077 & 1.000 & \\
\hline 12. OWN_CON & $-0.112 * *$ & $-0.117 * *$ & 0.063 & 0.04 & $0.097 *$ & 1.000 \\
\hline $\mathrm{N}$ & 606 & 606 & 606 & 606 & 606 & 606 \\
\hline
\end{tabular}

$*$ and $* *$ indicate statistical significance at the $5 \%$ and $1 \%$ levels in two-tailed t-tests, respectively. The variables are defined in Appendix A. 


\subsection{Results of Regression Analyses}

\subsubsection{Relationship Between ID And CSR}

The multivariate regression results are shown in Table 3, Table 4, and Table 5, and we present the beta coefficient, i.e., the standardized coefficient, that assists the researcher in interpreting the degree of influence that the independent variables have on the dependent variable on a relative basis. Thus, we see the relative importance of the variable of interest (INTL_DIV) and other control variables on CSR_SCORE (dependent variable).

Table 3 reports the results of multivariate regression analyses. Because the residuals are correlated across time and/or firms for pooled sample regression analyses, we present t-statistics based on robust standard errors at the firm and year levels. We report in regression (1) using the entire sample. We see that INTL_DIV is significantly and negatively associated with CSR_SCORE $(-0.100,2.13$ (t-statistics)) as predicted, suggesting that firms engaged in more ID tend to perform fewer CSR activities in the domestic market. This result supports our first hypothesis (H1) that a significant relationship exists between MNCs' ID and CSR activities in the domestic market. The result also shows the negative relationship between ID and CSR in the domestic market, suggesting the synergy effect of ID and/or the decreasing importance of the domestic market compared with MNCs' total markets.

Regressions (2) and (3) in Table 3 show the results of the test for whether chaebol firms' CSR activities differ from those of non-chaebol firms. We divide the sample into two groups: chaebol (30 largest business groups) and non-chaebol. The estimated coefficient for INTL_DIV is negative and statistically significant $(-0.251,-2.39$ (tstatistics)) for chaebol firms. In contrast, the estimated coefficient for INTL_DIV is negative but insignificant for non-chaebol firms, supporting our second hypothesis (H2) that the corporate governance of chaebols strengthens the relationship between MNCs' ID and CSR activities in the domestic market. This result suggests that the corporate governance of chaebol firms is likely to affect the relationship between ID and CSR activities in the domestic market because of economy of scope or of relatively less importance on the domestic market.

Turning to control variables in regression (1), the coefficients for $R D_{-} I N T$, AD_INT, ASEET_AGE, SIZE, ROS, and SLACK are positive and significant (more than two stars indicate that $\mathrm{p}<0.05$ ). Specially, the coefficients (t-statistics) for SIZE, RD_INT, and $A D_{-} I N T$ are 0.560 (8.70), 0.150 (3.35), and 0.203 (5.74), respectfully, suggesting that firms' size, R\&D, and advertisement positively influence CSR activities that contribute to enhancing a firm's reputation and brand image, as expected. With respect to our research model, the independent variables have reasonable explanatory power to predict the dependent variable, as indicated by the adjusted $\mathrm{R}^{2}$ values of $0.52,0.53$, and 0.38 for regressions (1), (2), and (3), respectively. Because the VIF values in Table 3 are less than 3.47 , we may conclude that no multicollinearity problem exists. 
Table 3: Multiple Regressions Of CSR On ID

\begin{tabular}{|c|c|c|c|c|}
\hline \multirow[t]{3}{*}{ Independent Variables } & \multirow[t]{3}{*}{ Predicted Sign } & \multicolumn{3}{|c|}{ Dependent Variable } \\
\hline & & (1) All Sample & (2) Chaebol & (3) Non-Chaebol \\
\hline & & $\underset{\substack{\text { (t-stat) } \\
\text { CSR_SCORE }}}{\text { antate }}$ & $\underset{\substack{\text { (t-stat) } \\
\text { CSR_SCORE }}}{ }$ & $\underset{\text { (t-stat) }}{\text { CSR_SCORE }}$ \\
\hline$I N T L \_D I V$ & - & $\begin{array}{c}-0.100 * * \\
(-2.13)\end{array}$ & $\begin{array}{c}-0.251 * * \\
(-2.39)\end{array}$ & $\begin{array}{l}-0.066 \\
(-1.16)\end{array}$ \\
\hline$R D \_I N T$ & + & $\begin{array}{c}0.150 * * * \\
(3.35) \\
\end{array}$ & $\begin{array}{l}0.196 \\
(1.40) \\
\end{array}$ & $\begin{array}{c}0.170 * * * \\
(3.05)\end{array}$ \\
\hline$A D \_I N T$ & + & $\begin{array}{c}0.203 * * * \\
(5.74)\end{array}$ & $\begin{array}{c}0.134^{*} \\
(1.81) \\
\end{array}$ & $\begin{array}{c}0.405 * * * \\
(6.31) \\
\end{array}$ \\
\hline RISK & $+1-$ & $\begin{array}{l}-0.038 \\
(-1.01) \\
\end{array}$ & $\begin{array}{c}-0.142 * \\
(-1.66) \\
\end{array}$ & $\begin{array}{l}-0.022 \\
(-0.49) \\
\end{array}$ \\
\hline$A S S E T \_A G E$ & + & $\begin{array}{c}0.116 * * * \\
(3.18)\end{array}$ & $\begin{array}{l}-0.061 \\
(-0.69)\end{array}$ & $\begin{array}{c}0.163 * * * \\
(3.29)\end{array}$ \\
\hline SIZE & + & $\begin{array}{c}0.560 * * * \\
(8.70) \\
\end{array}$ & $\begin{array}{c}0.561 * * * \\
(3.13) \\
\end{array}$ & $\begin{array}{c}0.347 * * * \\
(5.08) \\
\end{array}$ \\
\hline$R O S$ & + & $\begin{array}{c}0.090 * * \\
(2.10) \\
\end{array}$ & $\begin{array}{l}0.017 \\
(0.17) \\
\end{array}$ & $\begin{array}{l}0.056 \\
(1.13) \\
\end{array}$ \\
\hline SLACK & + & $\begin{array}{c}0.108 * * * \\
(3.22)\end{array}$ & $\begin{array}{l}0.173 \\
(1.50)\end{array}$ & $\begin{array}{c}0.147 * * * \\
(3.19)\end{array}$ \\
\hline$I N S T$ & + & $\begin{array}{l}0.044 \\
(1.50)\end{array}$ & $\begin{array}{l}0.098^{*} \\
(1.81) \\
\end{array}$ & $\begin{array}{l}0.026 \\
(0.73) \\
\end{array}$ \\
\hline FORE & + & $\begin{array}{l}0.020 \\
(0.48) \\
\end{array}$ & $\begin{array}{l}0.132 \\
(1.13)\end{array}$ & $\begin{array}{l}-0.065 \\
(-1.16)\end{array}$ \\
\hline OWN_CON & - & $\begin{array}{l}-0.039 \\
(-1.12) \\
\end{array}$ & $\begin{array}{c}-0.136^{*} \\
(-1.77) \\
\end{array}$ & $\begin{array}{l}0.033 \\
(0.68) \\
\end{array}$ \\
\hline Industry dummies & & Included & Included & Included \\
\hline Year dummies & & Included & Included & Included \\
\hline Adj. $\mathrm{R}^{2}$ & & 0.52 & 0.53 & 0.38 \\
\hline $\mathrm{F}$ & & $22.29 * * *$ & $14.49 * * *$ & $10.83 * * *$ \\
\hline Mean of VIF & & 1.88 & 3.47 & 2.00 \\
\hline $\mathrm{N}$ & & 606 & 171 & 435 \\
\hline
\end{tabular}

*, **, and *** indicate statistical significance at the $10 \%, 5 \%$, and $1 \%$ levels in two-tailed t-tests, respectively. The variables are defined in Appendix A. All test statistics and significance levels are calculated based on the robust standard error adjusted for heteroskedasticity at the firm and year levels.

\subsection{Relationship Between Individual Indicator Of ID And CSR: Robustness Test}

To check the robustness of our results in Table 3, we construct a separate ID measure for each of the three indicators: export portion of total sales (INTL_DIV_EXPORT), number of affiliates (INTL_DIV_AFF), and number of countries (INTL_DIV_COUNT). We then examine the relationship between CSR_SCORE and each of the three individual indicators, as well as two individual indicators. To do so, we run the multiple regressions from (1) to (5) of Table 5.

The results of the variables of interest are partially presented in Table 4 because the results of the control variables are similar to those of Table 3. As shown in Table 4, the coefficients for INTL_DIV_EXPORT, $I N T L \_D I V \_A F F$, and INTL_DIV_COUNT are negative $(-0.135,-0.120$, and -0.122 , respectively) and significant (all p < 0.01) in regressions (1), (2), and (3), suggesting that all three individual indicators are statistically significant in explaining firms' CSR activities in the domestic market. Additionally, in regressions (4) and (5), the coefficients 
for INTL_DIV_EXPORT and INTL_DIV_AFF, and for INTL_DIV_EXPORT and INTL_DIV_COUNT, are all negative $(-0.135,-0.120,-0.132,-0.120$, respectively) and significant $(\mathrm{p}<0.01)$. These results suggest that the number of affiliates and the number of countries appear to be important ID measures, although the results are very similar to those obtained using only the INTL_DIV_EXPORT variable.

The adjusted $\mathrm{R}^{2}$ of regression models (1) through (5) is at least 0.52 , showing reasonable explanatory power of the independent variables on the dependent variable (CSR_SCORE). The VIF values in Table 4 are less than 2.01, enabling us to conclude that no multicollinearity problem exists. Taken together, this evidence supports the contention that ID is negatively associated with CSR in the domestic market. In addition, we find that both the number of affiliates $\left(I N T L_{-} D I V \_A F F\right)$ and the number of countries (INTL_DIV_COUNT) explain CSR activities of Korean firms and the export portion of total sales in terms of the significance of the coefficients and the adjusted $\mathrm{R}^{2}$.

Table 4: Multiple Regressions Of Components Of ID On CSR

\begin{tabular}{|c|c|c|c|c|c|c|}
\hline \multirow{4}{*}{$\begin{array}{c}\text { Independent } \\
\text { Variables } \\
\end{array}$} & \multirow{4}{*}{ Predicted Signs } & \multicolumn{5}{|c|}{ Components of International Diversification } \\
\hline & & \multicolumn{5}{|c|}{ Dependent Variable } \\
\hline & & $(1)$ & $(2)$ & (3) & (4) & (5) \\
\hline & & $\begin{array}{c}\text { CSR_SCORE } \\
\text { (t-stat) }\end{array}$ & $\begin{array}{c}\text { CSR_SCORE } \\
\text { (t-stat) }\end{array}$ & $\begin{array}{c}\text { CSR_SCORE } \\
\text { (t-stat) }\end{array}$ & $\begin{array}{c}\text { CSR_SCORE } \\
\text { (t-stat) }\end{array}$ & $\begin{array}{c}\text { CSR_SCORE } \\
\text { (t-stat) }\end{array}$ \\
\hline$I N T L \_D I V \_E X P O R T$ & - & $\begin{array}{c}-0.135 * * * \\
(-2.83)\end{array}$ & & & $\begin{array}{c}-0.135 * * * \\
(-2.82)\end{array}$ & $\begin{array}{c}-0.132 * * * \\
(-2.76)\end{array}$ \\
\hline$I N T L \_D I V \_A F F$ & - & & $\begin{array}{c}-0.120 * * * \\
(-4.05)\end{array}$ & & $\begin{array}{c}-0.120 * * * \\
(-4.11)\end{array}$ & \\
\hline$I N T L \_D I V \_C O U N T$ & - & & & $\begin{array}{c}-0.122 * * * \\
(-4.43) \\
\end{array}$ & & $\begin{array}{c}-0.120 * * * \\
(-4.42) \\
\end{array}$ \\
\hline Control variables & & Included & Included & Included & Included & Included \\
\hline Industry dummies & & Included & Included & Included & Included & Included \\
\hline Year dummies & & Included & Included & Included & Included & Included \\
\hline Adj. $R^{2}$ & & 0.52 & 0.52 & 0.53 & 0.53 & 0.53 \\
\hline $\mathrm{F}$ & & $21.23 * * *$ & $23.90 * * *$ & $24.04 * * *$ & $23.66 * * *$ & $23.71 * * *$ \\
\hline Mean of VIF & & 1.95 & 1.81 & 1.8 & 1.96 & 1.95 \\
\hline $\mathrm{N}$ & & 606 & 606 & 606 & 606 & 606 \\
\hline
\end{tabular}

*, **, and $* * *$ indicate statistical significance at the $10 \%, 5 \%$, and $1 \%$ levels in two-tailed t-tests, respectively. All test statistics and significance levels are calculated based on the robust standard error adjusted for heteroskedasticity at the firm and year levels. All other variables are defined in Appendix A.

Variable Definitions:

$I N T L \_D I V \_E X P O R T=$ export portion of net sales, standardized value of (export amount / net sales);

$I N T L \_D I V \_A F F=$ number of subsidiaries, standardized value of the number of subsidiaries held by firms at yearend; and,

$I N T L \_D I V \_C O U N T=$ total number of countries in which subsidiaries are located, standardized value of the total number of countries at year-end. 


\section{4 Chaebol}

We perform additional tests to determine whether the governance structure of chaebols still affects the relationship between three individual indicators of ID and CSR in the domestic market. The results of the variables of interest are partially presented in Table 5 because the results of the control variables are similar to those of Table 4. Panel A of Table 5 shows the results for regressions (1) through (5) using a separate measure of ID for the chaebol group. The coefficients for INTL_DIV_EXPORT, INTL_DIV_AFF, and INTL_DIV_COUNT (regressions (1) to (3)) are all negative $(-0.508,-0.252$, and -0.235 , respectively) and significant ( $\mathrm{p}<0.01)$. Further, in regression (4), the coefficients for INTL_DIV_EXPORT and INTL_DIV_AFF $(-0.495,-0.244)$ are all negative and significant ( $\mathrm{p}<0.01)$. In regression (5), the coefficients for INTL_DIV_EXPORT and INTL_DIV_COUNT are also negative ($0.485,-0.221)$ and significant $(\mathrm{p}<0.01)$. These results suggest that all three individual indicators and each combination of two indicators are statistically significant in explaining firms' CSR. In regressions (4) and (5), we use both alternative indicators and traditional measures of ID, i.e., INTL_DIV_EXPORT, to determine whether alternative measures of ID have additional explanatory power on CSR_SCORE. We find that the negative coefficients of the export portion of total sales (INTL_DIV_EXPORT) are larger than that of other variables (INTL_DIV_AFF and INTL_DIV_COUNT) in both regressions (4) and (5).

The interpretation of these results is that the export portion of total sales influences CSR activities in the domestic market more than the number of affiliates and the number of countries. Additionally, the adjusted coefficients of the determination $\mathrm{R}^{2}$ of regressions (4) and (5) are 3-4 percentage points larger than that of regressions (1), (2), and (3), indicating that the explanatory powers of the model increase by using one more variable, i.e., INTL_DIV_AFF or INTL_DIV_COUNT. We do not put all three variables into a single regression model due to the very high correlation of alternative measures of ID, i.e., INTL_DIV_AFF and INTL_DIV_COUNT $(0.9842, \mathrm{p}<0.01)$, which may cause multicollinearity problems. The correlation coefficients (untabulated) of $I N T L \_D I V \_E X P O R T$ and INTL_DIV_AFF, and of INTL_DIV_EXPORT and INTL_DIV_COUNT, are 0.1344 and 0.1409 , respectively, and all are significant $(\mathrm{p}<0.01)$.

In contrast, as shown in Panel B of Table 5, we find that no significant relationship exists between ID and CSR for chaebol firms in the domestic market, suggesting that non-chaebol firms do not seem to realize synergy effects, as do chaebol firms. Our regression models (1) through (5) have an adjusted $\mathrm{R}^{2}$ value of at least 0.52 for the chaebol group (Panel A) and 0.38 for the non-chaebol group (Panel B), indicating acceptable explanatory power. To summarize, the evidence supports $\mathbf{H 2}$, which states that the corporate governance of chaebols strengthens the relationship between MNCs' ID and CSR activities in the domestic market. Given that economies of scope may be realized through ID, it is important to note that chaebol firms appears to utilize CSR activities in the domestic market more efficiently than non-chaebol firms. Thus, MNCs might reconsider whether the level of CSR activity is appropriate by taking into account their overall business strategy in this study, such as ID. 
Table 5: Multiple Regressions Of CSR On Components Of ID

\begin{tabular}{|c|c|c|c|c|c|}
\hline \multicolumn{6}{|l|}{ Panel A: Chaebol Group } \\
\hline \multirow{4}{*}{ Independent Variables } & \multicolumn{5}{|c|}{ Components of International Diversification } \\
\hline & \multicolumn{5}{|c|}{ Dependent Variable } \\
\hline & $(1)$ & $(2)$ & (3) & (4) & $(5)$ \\
\hline & $\underset{\substack{\text { (t-stat) } \\
C S R_{-} S C O R E}}{ }$ & $\underset{\substack{\text { (t-stat) } \\
\text { CSR_SCORE }}}{ }$ & $\begin{array}{c}\text { CSR_SCORE } \\
\text { (t-stat) }\end{array}$ & $\underset{\substack{\text { (t-stat) } \\
\text { CSR_SCORE }}}{\text { S }}$ & $\underset{\substack{\text { (t-stat) } \\
C S R_{\text {f }} S C O R E}}{ }$ \\
\hline$I N T L \_D I V \_E X P O R T$ & $\begin{array}{c}-0.508 * * * \\
(-3.19)\end{array}$ & & & $\begin{array}{c}-0.495 * * * \\
(-3.27)\end{array}$ & $\begin{array}{c}-0.485 * * * \\
(-3.19)\end{array}$ \\
\hline$I N T L \_D I V \_A F F$ & & $\begin{array}{c}-0.252 * * * \\
(-3.03)\end{array}$ & & $\begin{array}{c}-0.244 * * * \\
(-2.88)\end{array}$ & \\
\hline$I N T L \_D I V \_C O U N T$ & & & $\begin{array}{c}-0.235^{* * *} \\
(-3.00) \\
\end{array}$ & & $\begin{array}{c}-0.221 * * * \\
(-2.76) \\
\end{array}$ \\
\hline Control variables & Included & Included & Included & Included & Included \\
\hline Industry dummies & Included & Included & Included & Included & Included \\
\hline Year dummies & Included & Included & Included & Included & Included \\
\hline Adj. $R^{2}$ & 0.55 & 0.54 & 0.54 & 0.58 & 0.58 \\
\hline Mean of VIF & 3.91 & 3.34 & 3.31 & 3.45 & 2.01 \\
\hline $\mathrm{N}$ & 171 & 171 & 171 & 171 & 171 \\
\hline
\end{tabular}

Panel B: Non-Chaebol

\begin{tabular}{|c|c|c|c|c|c|}
\hline \multirow{4}{*}{ Independent Variables } & \multicolumn{5}{|c|}{ Components Of International Diversification } \\
\hline & \multicolumn{5}{|c|}{ Dependent Variable } \\
\hline & (1) & (2) & (3) & (4) & (5) \\
\hline & $\begin{array}{c}C S R \_S C O R E \\
\text { (t-stat) }\end{array}$ & $\begin{array}{c}C S R \_S C O R E \\
\text { (t-stat) }\end{array}$ & $\begin{array}{c}\text { CSR_SCORE } \\
\text { (t-stat) }\end{array}$ & $\begin{array}{c}\text { CSR_SCORE } \\
\text { (t-stat) }\end{array}$ & $\begin{array}{c}C S R \_S C O R E \\
\text { (t-stat) }\end{array}$ \\
\hline$I N T L \_D I V \_E X P O R T$ & $\begin{array}{l}-0.070 \\
(-1.11) \\
\end{array}$ & & & $\begin{array}{l}-0.105 \\
(-1.65) \\
\end{array}$ & $\begin{array}{c}-0.054 \\
(-0.82) \\
\end{array}$ \\
\hline$I N T L \_D I V \_A F F$ & & $\begin{array}{l}-0.037 \\
(-0.90)\end{array}$ & & $\begin{array}{c}-0.069 * \\
(-1.83)\end{array}$ & \\
\hline$I N T L \_D I V \_C O U N T$ & & & $\begin{array}{l}-0.054 \\
(-1.56) \\
\end{array}$ & & $\begin{array}{r}-0.039 \\
(-1.11) \\
\end{array}$ \\
\hline Control variables & Included & Included & Included & Included & Included \\
\hline Industry dummies & Included & Included & Included & Included & Included \\
\hline Year dummies & Included & Included & Included & Included & Included \\
\hline Adj. $\mathrm{R}^{2}$ & 0.38 & 0.38 & 0.38 & 0.39 & 0.38 \\
\hline Mean of VIF & 2.05 & 1.89 & 1.93 & 1.94 & 2.09 \\
\hline $\mathrm{N}$ & 435 & 435 & 435 & 435 & 435 \\
\hline
\end{tabular}

*, **, and *** indicate statistical significance at the $10 \%, 5 \%$, and $1 \%$ levels in two-tailed t-tests, respectively. All test statistics and significance levels are calculated based on the robust standard error adjusted for heteroskedasticity at the firm and year levels. All variables are defined in Appendix A. 


\section{SUMMARY AND CONCLUSIONS}

Our primary motivation for this study is to determine whether the level of CSR activities in the domestic market increases or decreases as MNCs' ID progresses. The growing importance of CSR and ID (Sharfman et al. 2004) for MNCs' strategies and the little empirical evidence on the relationship between ID and CSR (Strike et al. 2006; Kang 2013) drive us to investigate the relationship between ID and CSR in the domestic market. McWilliams and Siegel (2001) suggest that a proper level of CSR activities exists to realize maximum profits. We further question whether a proper level of CSR activities exists by considering firms' ID strategy and governance structure. To answer this question, we also examine whether the corporate governance structure characterized by the Korean chaebol system affects the relationship between ID and CSR in the domestic market.

We find that MNCs' ID is negatively associated with CSR activities in the domestic market. One interpretation of this result is that MNCs are likely to realize the economy of scope and synergy effects through ID. Ghoshal (1987, p. 428) suggests that MNCs realize economies of scope by sharing investments and costs across products, markets, and businesses. McWilliams and Siegel (2001, p. 125) also suggest that "the likelihood of economies of scale and scope in the provision of CSR implies that large, diversified companies will be more active in this arena." Another interpretation is that as MNCs expand overseas, the domestic market becomes less important relative to the total markets in which MNCs engage. In addition, we also find that this negative relationship is stronger for chaebol firms, suggesting that such firms appear to perform CSR more efficiently than non-chaebol firms by fitting domestic market CSR activities into their ID strategy. ${ }^{\mathrm{xv}}$ Alternatively, chaebol firms seem to reduce CSR activities in the domestic market due to decreasing importance on the domestic market relative to MNCs' global market. If firms are able to fit their specific strategy into an overall business strategy, they are likely to experience a competitive advantage and perform better financially (Porter 1996). Our findings support the contention that chaebols in Korea are likely to realize higher profitability than non-chaebols (Chang and Choi 1988; Shin and Park 1999; Chang and Hong 2000).

In addition, we separately and collectively employ three indicators of ID to test the robustness of our result. The results show that CSR in the domestic market is negatively and significantly associated with (1) the export portion of total sales; (2) the number of foreign affiliates; and (3) the number of countries. The effect of chaebol firms on this relationship is greater than that of non-chaebols, either indicating that chaebols appear to utilize CSR activities by efficiently taking into account ID strategy or reflecting a decrease in the relative importance of the domestic market compared with the total market.

Although generalizing results from a single study is difficult, our findings provide contributions and implications for scholars, practitioners, and regulations setters as follows. First, for academics, our study reports the first empirical findings on the significant relationship between ID of MNCs and CSR in the domestic market for Korean manufacturing MNCs. When the importance of ID and CSR in formulating Korean firms' global strategies gains more attention than before and little empirical evidence exists on this issue to date, the results of this study can be a stepping stone for future studies that explore issues related to ID and/or CSR for MNCs, such as the relationships between CSR and firm value. Second, practitioners can reconsider whether a proper level of CSR activities exists considering their business strategies, such as ID. McWilliams and Siegel (2001) conclude that an optimal level of CSR exists, and that cost-benefit analysis is able to determine this ideal level. Porter (1996) also argues that if firms are able to fit their specific strategy into their overall business strategy, they may have a competitive advantage and perform better financially. Accordingly, our study suggests that practitioners should determine how they fit their CSR strategy into their ID strategy. Lastly, policymakers can recognize the fact that a high level of CSR activities is not always best for firms. The results of our study imply that ID and corporate governance are likely to affect CSR activities in the domestic market. Thus, before encouraging firms to perform CSR activities by enacting laws, policymakers should consider the importance of firms' characteristics, strategies, and governance structures to provide the best business environment under which firms are able to enhance their competitive advantage.

Our findings should be interpreted with the following limitations in mind. First, our method and tests implicitly assume that our sample firms are adequate for generalizing the relationship between ID and CSR in the domestic market. We restrict our sample to Korean-listed manufacturing firms from 2005 to 2010. Second, as with 
any empirical study, we may have measurement errors related to ID and CSR. Although we attempt to calculate and use sophisticated ID measures, future studies may contain more indicators, such as foreign asset proportion and the number of employees in foreign countries. Although our CSR measure is widely utilized and accepted in academia and among practitioners, alternative CSR measures may exist that better capture the comprehensive concept of CSR and reflect recent CSR trends. Addressing these issues in future studies would be worthwhile.

\section{AUTHOR INFORMATION}

Eunho Cho, Ph.D and Adjunct Professor of Accounting has been teaching at Sogang University since 2012 and Korea Banking Institution since 2003, respectively. He has been majoring the BA (Accounting) to achieve doctor degree at Sogang University since 2010. He received the Master of Financial Engineering degree from KAIST. He also worked for finance and manufacturing company for 9 years and 4 years, respectively. His research focuses on the CSR, earnings management, corporate governance, international business, and valuation. He achieved the certificate of CFA, AICPA and FRM which are conferred by US based institutions. Eunho Cho, School of Business, Sogang University, 35 Baekbumro Mapogu, Seoul, Korea, 121-742. E-mail: anselm@ sogang.ac.kr (corresponding author).

Dr. Sungbin Chun is a Professor of Accounting with Business School at Sogang University, AACSB accredited school. She received her Ph.D. degree in Accounting from the University of California Berkeley. She has been teaching at Sogang University since 1986. Sungbin Chun, School of Business, Sogang University, 35 Baekbumro Mapogu, Seoul, Korea, 121-742. E-mail: younghwa@sogang.ac.kr (Corresponding author).

Donseung, Choi, Ph.D candidate and lecturer of Business Administration (BA) has been majoring the BA (International Business) to achieve doctor degree at Sogang University since 2011. He received the Master of Economics degree from Sogang University. His research interests are primarily in the areas of international finance, international business, FDI, and entrepreneurship. Donseung, Choi, School of Business, Sogang University, 35 Baekbumro Mapogu, Seoul, Korea, 121-742. E-mail: dschoi@sogang.ac.kr.

\section{REFERENCES}

Aguinis, H., \& Glavas A. (2012). What we know and don't know about corporate social responsibility: A review and research agenda. Journal of Management, 38(4), 932-968.

Albrecht, C., Turnbull, C., Zhang, Y., \& J. Skousen, C. (2010). The relationship between south korean chaebols and fraud. Management Research Review, 33(3), 257-268.

Alexander, G. J., \& Buchholz, R. A. (1978). Corporate social performance and stock market performance. Academy of Management Journal, 21, 479-486.

Belal, A. (2001). A study of corporate social disclosures in Bangladesh. Managerial Auditing Journal, 16(5), 274289.

Bowen, H. R. (1953). Social Responsibilities of the Businessman. New York: Harper \& Row.

Brammer, S. J., \& Pavelin, S. (2006a). Corporate reputation and social performance: The importance of fit. Journal of Management Studies, 43, 435-455.

Brammer, S. J., \& Pavelin, S. (2006b). Voluntary environmental disclosures by large UK companies. Journal of Business Finance \& Accounting, 33, 1168-1188.

Brown, P., Beekes, W., \& Verhoeven, P. (2011). Corporate governance, accounting and finance: A review. Accounting and Finance, 51, 96-172.

Campbell II, T. L., \& Keys, P. Y. (2002). Corporate governance in South Korea: the chaebol experience. Journal of Corporate Finance, 8, 373-391.

Carroll, A. B. (1979). A three-dimensional conceptual model of corporate social performance. Academy of Management Review, 4, 497-505.

Carroll, A. B. (1991). The pyramid of corporate social responsibility: Toward the moral management of organizational stakeholders. Business Horizons, 34(4), 39-48.

Carroll, A. B. (1993). Business \& society: Ethics and stakeholder management. 2nd ed., South-Western Publishing.

Carroll, A. B., \& Shabana, K. M. (2010). The business case for corporate social responsibility: A review of concepts, research and practice. International Journal of Management Reviews, 12(1), 85-105. 
Chang, S. J., \& Hong, J. (2000). Economic performance of the group-affiliated companies in Korea: Resource sharing and internal business transactions. Academy of Management Journal, 43(3), 429-448.

Choi, B., Lee, D., \& Park, Y. (2013). Corporate social responsibility, corporate governance and earnings quality: Evidence from Korea. Corporate Governance: An International Review, 21(5), 447-467.

Choi, J. S., Kwak, Y. M., \& Choe, C. (2010). Corporate social responsibility and corporate financial performance: Evidence from Korea. Australian Journal of Management, 35, 291-311.

Choi, S., \& Aguilera, R. V. (2009). CSR dynamics in South Korea and Japan: A Comparative analysis, In C. A. Mallin (Ed.). Corporate Social Responsibility: A case study approach (pp. 123-147). Northampton, MA: Edward Elgar.

Christmann, P. (2004). Multinational companies and the natural environment: determinants of global environmental policy standardization. Academy of Management Journal, 47(5), 747-760.

Cochran, P. L., \& Wood, R. A. (1984). Corporate social responsibility and financial performance. Academy of Management Journal, 27(1), 42-56.

Cretu, R. F. (2012). Corporate governance and corporate diversification strategies. Review of International comparative management, 13(4), 621-633.

Daft, R. (2010). Understanding in the Theory and Design of Organizations. 10th ed., South Western.

Dahlsrud, A. (2008). How corporate social responsibility is defined: An analysis of 37 definitions. Corporate Social Responsibility and Environmental Management, 15, 1-13.

Errunza, V., \& Senbet, L. (1981). The effects of international operations on market value of the firm: Theory and evidence. Journal of Finance, 36, 401-417.

Errunza, V., \& Senbet, L. (1984). International corporate diversification, market valuation, and size-adjusted evidence. Journal of Finance, 34, 727-745.

Finkelstein, S. (1992). Power in top management teams: Dimensions, measurement, and validation. Academy of Management Journal, 35, 505-538.

Friedman, M. (1970). The social responsibility of business is to increase its profit. New York Times Magazine, September 13th, 32-33.

Freeman, R. E. (1984). Strategic management: A stakeholder approach. Pitman.

Gao, Y. (2011). CSR in an emerging country: A content analysis of CSR reports of listed companies. Baltic Journal of Management, 6(2), 263-291.

Ghoshal, S. (1987). Global strategy: An organizing framework. Strategic Management Journal, 8, 425-440.

Granovetter, M. (1995). Coase revisited: Business groups in the modern economy. Industrial and Corporate Change, 4(1), 93-130.

Graves, S. B., \& Waddock, S. A. (1994). Institutional owners and corporate social performance. Academy of Management Journal, 37, 1034-1046.

Hart, O., \& Moore, J. (1990). Property rights and the nature of the firm. Journal of Political Economy, 98, 11191158.

Hitt, M. A., Hoskisson, R. E., \& Kim, H. C. (1997). International diversification: Effects on innovation and firm performance in product-diversified firms. Academy of Management Journal, 40(4), 767-798.

Idowu, S. O., \& Towler, B. A. (2004). A comparative study of the contents of corporate social responsibility reports of UK companies. Management of Environmental Quality: An International Journal, 15(4, 420-437.

Ip, P. K. (2008). Corporate social responsibility and crony capitalism in Taiwan. Journal of Business Ethics, 79, 167-177.

Jensen, M., \& Meckling, W. (1976). Theory of the firm: Managerial behavior, agency cost and capital structure. Journal of Financial Economics, 3(4), 305-360.

Kang, J. (2013). The relationship between corporate diversification and corporate social performance. Strategic Management Journal, 34, 94-109.

KEJI (2011). The $20^{\text {th }}$ KEJI award information package. KEJI.

Kienzle, R., \& Shadur, M. (1997). Development on business networks in east Asia. Management Decision, 35(1), 23-32.

Kogut, B. (1985). Designing global strategies: Comparative and competitive value added chain. Sloan Management Review, 27(1), 15-28.

KPMG (2008). International survey of corporate responsibility reporting 2008, Available at: http://www.kpmg.com/global/en/issuesandinsights/articlespublications/pages/sustainabilitycorporateresponsibility-reporting-2008.aspx. 
Lee, S. M., Yoo, S., \& Lee, T. M. (1991). Korean Chaebols: Corporate Values and Strategies. Organizational Dynamics, 19(4), 36-50.

Low, P. \& Yeats, A. (1992). Do 'dirty' industries migrate? in P. Low (ed.) International Trade and the Environment. World Bank: Washington, DC, 89-104.

Lucas, R. E. B., Wheeler, D., \& Hettige, H. (1992). Economic development, environmental regulation and the international migration of toxic industrial pollution, 1960-1988, in P. Low(ed.). International Trade and the Environment, World Bank: Washington, DC, 67-88.

Majumdar, S. K., \& Ramaswamy, V. (1995). Going direct to market: The influence of exchange conditions. Strategic Management Journal, 16(5), 353-372.

Matten, D., Crane, A., \& Chapple, W. (2003). Behind de mask: revealing the true face of corporate citizenship. Journal of Business Ethics, 45, 109-120.

McGuire, J., Dow, S., \& Argheyd, K. (2003). CEO incentives and corporate social performance. Journal of Business Ethics, 45(4), 341-359.

McWilliams, A., \& Siegel, D. (2000). Corporate social responsibility and financial performance: Correlation or misspecification? Strategic Management Journal, 21, 603-609.

McWilliams, A., \& Siegel, D. (2001). Corporate social responsibility: A theory of the firm perspective. Academy of Management Review, 26(1), 117-127.

McWilliams, A., Siegel, D., \& Wright, P. (2006). Corporate social responsibility: A theory of the firm perspective. Academy of Management Studies, 43(1), 1-18.

Miles, M. P., \& Covin, J. G. (2000). Environmental marketing: A source of reputational, competitive, and financial advantage. Journal of Business Ethics, 23, 299-311.

Montiel, I. (2008). Corporate social responsibility and corporate sustainability: Separate pasts, common futures. Organization \& Environment, 21(3), 245-269.

Munilla, L. S., \& Miles, M. P. (2005). The corporate social responsibility continuum as a component of stakeholder theory. Business and Society Review, 110(4), 371-387.

Oh, W. Y., Chang, Y. K., \& Martynov, A. (2011). The effect of ownership structure on corporate social responsibility: Empirical evidence from Korea. Journal of Business Ethics, 104, 283-297.

Orlitzky, M., \& Benjamin, J. D. (2001). Corporate social performance and firm risk: A meta-analytic review. Business \& Society, 40(4), 369-396.

Orlitzky, M., Schmidt, F. L., \& Rynes, S. L. (2003). Corporate social and financial performance: A meta-analysis. Organization Studies, 24, 403-441.

Park, S. R., \& Yuhn, K. H. (2012). Has the Korean chaebol model succeeded? Journal of Economic Studies, 39(2), 60-274.

Peloza, J. (2009). The challenge of measuring financial impacts from investments in corporate social performance. Journal of Management, 35, 1518-1541.

Porter, M. E. (1990). The competitive advantage of nations. Boston, The Free Press.

Porter, M. E. (1996). What is strategy? Harvard Business Review, 74(6), 61-78.

Porter, M. E., \& Kramer, M. R. (2002). The competitive advantage of corporate philanthropy. Harvard Business Review, 80(12), 57-68.

Rugman, A. M. (1979). International diversification and the multinational enterprise. Lexington Books: Lexington, MA.

Scholtens, B., \& Kang, F. (2012). Corporate social responsibility and earnings management: evidence from Asian economies. Corporate Social Responsibility and Environmental Management, 20(2), 95-112.

Shahrohk, M. S. (2002). A review of the literature on the market valuation of multinational firms. Managerial Finance, 28(3), 5-19.

Sharfman, M. P., Shaft, T. M., \& Tihanyi, L. (2004). A model of the global and institutional antecedents of highlevel corporate environmental performance. Business and Society, 43(1), 6-36.

Shin, H., \& Park, Y. S. (1999). Financing constraints and internal capital markets: evidence from Korean chaebols. Journal of Corporate Finance, 5(2), 169-191.

Steyn, B., \& Niemann, L. (2014) Strategic role of public relations in enterprise strategy, governance and sustainability-A normative framework. Public Relations Review, 40, 171-183.

Strike, V. M., Gao, J., \& Bansal, P. (2006). Being good while being bad: social responsibility and the international diversification of US firms. Journal of International Business Studies, 37, 850-862. 
Statistics Research Institute (2009). Business operation of Korean firms: structure, strategy, performance. Statistics Research Institute.

Van Marrewijk, M. (2003). Concept and definitions of CSR and corporate sustainability: between agency and communication. Journal of Business Ethics, 44, 95-105.

Waddock, S. A., \& Graves, S. B. (1997). The corporate social performance-financial performance link. Strategic Management Journal, 18, 303-319.

Williams, C. A., \& Aguilera, R. V. (2008). Corporate social responsibility in comparative perspective. In Oxford Handbook of Corporate Social Responsibility. edited by Crane, A., McWilliams, A., Matten, D., Moon, J., \& Siegel, D. 452-472. Oxford, U.K.: Oxford University Press.

Wood, J. J., \& Lodgson, J. M. (2002). Business citizenship: from individuals to organizations. Business Ethics Quarterly, 3, 59-94.

World Business Council for Sustainable Development (1999). Corporate social responsibility: Meeting changing expectations. World Business Council for Sustainable Development: Geneva.

Zaheer, S. (1995). 'Overcoming the Liability of Foreignness. Academy of Management Journal, 38(2), 341-363. 


\section{APPENDIX A VARIABLE DEFINITIONS}

\begin{tabular}{|c|c|}
\hline Variable & Definition \\
\hline \multicolumn{2}{|l|}{ Dependent Variables } \\
\hline CSR & Net CSR score, as measured by the KEJI Index. ${ }^{1)}$ \\
\hline \multicolumn{2}{|l|}{ Variable of Interest } \\
\hline$I N T L \_D I V$ & Standardized score combining three indicators using factor analysis. ${ }^{2)}$ \\
\hline \multicolumn{2}{|l|}{ Control variables } \\
\hline$R D \_I N T$ & R\&D intensity (R\&D expenses/net sales); \\
\hline$A D \_I N T$ & Advertising intensity (advertising expenses/net sales); \\
\hline RISK & Beta, as measured by systematic risk using the market model; \\
\hline$A S S E T \_A G E$ & Asset age, $-(\mathrm{PPE}$ net amount/PPE gross amount); \\
\hline SIZE & Natural logarithm of total assets, $\ln$ (total assets), at year-end; \\
\hline ROS & Return on sales (EBIT/lagged net sales); \\
\hline$S L A C K$ & Slack resources (current assets/current liabilities) at year-end; \\
\hline INST & $\begin{array}{l}\text { Institutional investors' ownership, the sum of the percentage of shares held by institution investors } \\
\text { at year-end; }\end{array}$ \\
\hline FORE & $\begin{array}{l}\text { Foreign investors' ownership, the sum of the percentage of shares held by foreign investors at } \\
\text { year-end; and, }\end{array}$ \\
\hline OWN_CON & $\begin{array}{l}\text { Ownership concentration, the sum of the percentage of shares held by the three largest } \\
\text { shareholders at year-end. }\end{array}$ \\
\hline \multicolumn{2}{|c|}{ Variable of Interest in Additional Test } \\
\hline INTL_DIV_EXPORT & Export portion of net sales, standardized value of (export amount/net sales); \\
\hline$I N T L \_D I V \_A F F$ & $\begin{array}{l}\text { Number of subsidiaries, standardized value of number of subsidiaries held by the firms at year- } \\
\text { end; and, }\end{array}$ \\
\hline$I N T L \_D I V \_C O U N T$ & $\begin{array}{l}\text { Total number of countries in which subsidiaries are located, standardized value of total number of } \\
\text { countries at year-end. }\end{array}$ \\
\hline
\end{tabular}

1) Measured using seven categories: soundness (20), fairness (11), social contribution (7), customer protection and satisfaction (7), environmental protection activity (10), employee satisfaction (10), and economic development contribution (10). 2) Three indicators consist of foreign market penetration (export amount/total sales amount) and foreign market presence (number of foreign subsidiaries held by firms and total number of countries in which affiliates are located). 


\section{ENDNOTES}

${ }^{\mathrm{i}}$ Examples of stakeholders include shareholders, employees, customers, supplier, and local communities, among others.

ii Stakeholder theory argues that stakeholder management increases firm value in the long run on the basis of trust and cooperation, although stakeholder management may require significant expenditures to maintain good relationships with stakeholders.

iii Peloza (2009) performed a meta analysis using 128 research studies on the relationship between CSR activities and firms' financial performance. The results reveal 59\% positive associations, $27 \%$ mixed associations, and $14 \%$ negative associations.

${ }^{\text {iv }}$ In 2010, the International Organization for Standardization (ISO) published the ISO26000 standard that was passed by 162 national standards bodies. This standard offers guidance to organizations worldwide on how to behave in a socially responsible manner and how to report CSR activities.

${ }^{v}$ Many studies report that CSR is specific to the culture and seems to differ across cultures (Carroll 1993). Williams and Aguilera (2008) also argue that the association between social performance and firm value is likely contingent on cultural and social norms. Daft (2010) argues that prior research results indicate the different management patterns of firms in the Europe, U.S., and Asia regions.

${ }^{\text {vi }}$ Chaebol is a Korean term for a conglomerate of the many companies clustered around one parent company, and a chaebol is a large business group in Korea. The Korean government classifies and controls chaebol groups, i.e., 30 of the largest business groups.

${ }_{\text {vii }} \mathrm{A}$ keiretsu is a business group in Japan.

viii Money Today, Jan. 22, 2014.

ix This definition by Carroll has been employed successfully by many researchers for more than 25 years (Carroll and Shabana 2010).

${ }^{x}$ The Statistics Research Institute (2009) reports that, as of December 31, 2007, 5,568 foreign affiliates of 2,395 Korean firms exist, of which manufacturing domestic firms and affiliates account for $75 \%$ and $73 \%$, respectively, indicating that manufacturing firms account for the largest portions of entire industries.

${ }^{x i}$ The data were provided by the KEJI to enable us to use the full CSR score data for research purposes.

xii To assess the reliability of the measures, we check Cronbach's $\alpha$, which is known to be acceptable if its value is larger than 0.6 .

xiii KSIC stands for Korea Standard Industrial Classification.

xiv The KEJI excludes firms with three-year consecutive deficits and less than a 1.0 interest coverage ratio when the KEJI Index is measured (KEJI 2011).

${ }^{x v}$ Miles and Covin (2000) suggest that the strategic perspective of CSR can increase firm value by enhancing a firm's efficiency. Munilla and Miles (2005, p. 375) argue that, "Firms that perceive CSR in terms of compliance will typically compete in commodity markets from a cost basis, while firms that leverage CSR in a strategic manner will have more options in developing strategy and creating competitive advantage." 